\title{
SISTEM PAKAR DIAGNOSIS PENYAKIT PADA KELINCI MENGGUNAKAN METODE CERTAINTY FACTOR
}

\author{
Ananda Ayu Zahara Burhani ${ }^{1}$, Budi Harijanto ${ }^{2}$, Hendra Pradibta ${ }^{3}$ \\ ${ }^{1}$ Program Studi Teknik Informatika, ${ }^{2,3}$ Jurusan Teknik Elektro, Politeknik Negeri Malang \\ 1ananda240292@gmail.com
}

\begin{abstract}
Abstrak
Kelinci adalah salah satu binatang yang dekat dengan manusia serta memiliki daya adaptasi tubuh yang tinggi. Namun kelinci tidak lepas dari ancaman penyakit. Perawatannya membutuhkan biaya lebih sehingga diperlukan suatu cara untuk mengetahui penyakit dan solusinya agar dapat melakukan tindakan-tindakan yang diperlukan. Untuk mengatasinya dibuat suatu media kepakaran yang dapat diakses oleh pemilik kelinci yang bersifat online. Sistem pakar harus mampu bekerja dalam ketidakpastian, sehingga ditambahkan metode Certainty Factor (CF) untuk mengatasi permasalahan tersebut. Sistem dikembangkan dengan menganalisis gejala-gejala penyakit yang diinputkan yang kemudian diolah menggunakan kaidah produksi dan perhitungan $\mathrm{CF}$. Hasil diagnosis sistem menampilkan kemungkinan-kemungkinan penyakit yang diderita kelinci dan memberikan solusi penanganan pada penyakit dengan nilai CF terbesar. Besar nilai CF bergantung pada besaran nilai CF inputan user, banyaknya kecocokan masukan gejala terhadap suatu penyakit, dan besar nilai CF pakar dari suatu gejala dengan penyakit. Ketepatan output sistem dibuktikan dari hasil validitas sistem dengan pakar.
\end{abstract}

Kata kunci : sistem pakar, penyakit kelinci, certainty factor (CF)

\section{Pendahuluan}

Kelinci adalah salah satu binatang yang dekat dengan manusia. Menurut Ermawati (2011), kelinci dijinakkan sejak 2000 tahun yang lalu dengan tujuan sebagai bahan pangan (penghasil daging), penghasil kulit dan wol, maupun sebagai peliharaan. Kelinci memiliki daya adaptasi tubuh yang tinggi sehingga mampu dikembangkan hampir di seluruh dunia. Akan tetapi kelinci tidak lepas dari ancaman serangan penyakit yang apabila dibiarkan dapat berdampak buruk. Penyakit-penyakit yang sering menyerang kelinci antara lain kembung dan mencret. Selain kedua penyakit tersebut, ada pula beberapa penyakit lain yang juga menyerang kelinci yaitu demodexcosis dan scabies yang menyerang kulit, radang mata, coccidiosis, cacingan, myxomatosis, sembelit, radang susu (young do syndrome/mastitis), serta radang paruparu (pneumonia).

Bila kelinci terserang penyakit, sering kali pemilik tidak tahu apa yang harus dilakukan. Terkadang bila pemilik harus ke dokter hewan untuk pengobatan, mereka memiliki kendala yaitu dokter hewan terdekat jauh jaraknya ataupun tidak memiliki waktu luang. Untuk mengatasi masalah tersebut dibuatlah suatu media kepakaran yang dapat diakses oleh pemilik kelinci yang bersifat online .

Pemanfaatan teknologi saat ini juga mencakup bidang kedokteran (medis), salah satunya di bidang Artificial Intelligence yang mengarah pada sistem pakar (Expert System). Menurut Milwati (2010), sistem pakar itu merupakan sistem yang berusaha mengadopsi pengetahuan manusia ke komputer, agar komputer dapat menyelesaikan masalah seperti yang biasa dilakukan oleh para ahli. Pengertian sistem pakar menurut Turban (Sutojo dkk, 2011) adalah sebuah sistem yang menggunakan pengetahuan manusia dimana pengetahuan tersebut dimasukkan ke dalam komputer dan kemudian digunakan untuk menyelesaikan masalah-masalah yang biasanya membutuhkan kepakaran atau keahlian manusia. Untuk memindahkan kepakaran, harus dikeahui terlebih dahulu cara kerja pakar tersebut. Pada penelitian ini pakar merupakan dokter hewan. Dokter hewan akan mendiagnosis penyakit yang diderita berdasarkan gejala yang muncul pada kelinci. Dari kesimpulan penyakit tersebut, baru diberilah solusi untuk mengobati penyakitnya. Sistem pakar ini diharapkan bisa membantu pemilik kelinci mendapatkan informasi diagnosis penyakit dan cara penanggulangan penyakit tersebut.

Selain itu, sistem pakar harus mampu bekerja dalam ketidakpastian yang salah satu metodenya adalah menggunakan certainty factor (CF). Definisi menurut David McAllister (Alatas dan Maulidia G., 2009), Certainty Factor adalah suatu metode untuk membuktikan apakah suatu fakta itu pasti ataukah tidak pasti yang berbentuk metric yang biasanya digunakan dalam sistem pakar. Metode ini sangat cocok untuk sistem pakar yang mendiagnosis sesuatu yang belum pasti.

Dalam penelitian ini yang menjadi masalah utama adalah bagaimana merancang dan membangun suatu sistem pakar berbasis web untuk membantu $u$ ser dalam mengetahui informasi diagnosis penyakit kelinci dengan menggunakan metode certainty factor (CF) yang menghasilkan solusi untuk membantu penanganan pada penyakit.

Adapun tujuan penelitian adalah untuk membangun sebuah sistem pakar yang dapat digunakan untuk mengenali dan mengetahui penyakit pada kelinci menggunakan metode certainty factor (CF) sehingga menghasilkan solusi untuk membantu penanganan pada penyakit. 


\section{Metode}

Metode yang digunakan adalah certainty factor (CF). Certainty Factor (CF) merupakan suatu metode yang digunakan untuk menyatakan kepercayaan dalam sebuah kejadian (fakta atau hipotesis) berdasarkan bukti atau penilaian pakar. Certainty Factor (CF) dapat terjadi dengan berbagai kondisi. Diantara kondisi yang terjadi adalah terdapat beberapa antensenden (dalam rule yang berbeda) dengan satu konsekuen yang sama (Sutojo dkk, 2011). CF digunakan sebagai panduan dalam melakukan proses penalaran. Untuk setiap jenis penyakit dan gejala, dibuatkan kode penyakit P00001..Pn serta kode gejala G00001..Gn.

Adapun rumusan dasar dari Certainty Factor, sebagai berikut :

a. Metode 'Net Belief' yang diusulkan oleh Shortliffe dan Buchanan yaitu:

$C F($ Rule $)=M B(H, E)-M D(H, E)$.

$$
\begin{aligned}
& M B(H, E)=\left\{\begin{array}{c}
1 \\
\frac{\max [P(H \mid E), P(H)]-P(H)}{\max [1,0]-P(H)} \mathrm{P}(\mathrm{H})=1
\end{array}\right.
\end{aligned}
$$

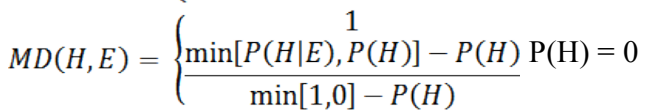

Dimana :

$\mathrm{CF}($ Rule $)=$ faktor kepastian

$\mathrm{MB}(\mathrm{H}, \mathrm{E})=$ measure of belief (ukuran kepercayaan) terhadap hipotesis $\mathrm{H}$, jika diberikan evidence $\mathrm{E}$ (antara 0 dan 1)

$\mathrm{MD}(\mathrm{H}, \mathrm{E})=$ measure of disbelief (ukuran ketidakpercayaan) terhadap evidence $\mathrm{H}$, jika diberikan evidence E (antara 0 dan 1)

$\mathrm{P}(\mathrm{H}) \quad=$ probabilitas kebenaran hipotesis $\mathrm{H}$

$\mathrm{P}(\mathrm{H} \mid \mathrm{E})=$ probabilitas bahwa $\mathrm{H}$ benar karena fakta $\mathrm{E}$

b. Dengan cara mewawancarai seorang pakar.

Nilai CF(Rule) didapat dari interpretasi "term" dari pakar, yang diubah menjadi nilai CF tertentu sesuai tabel berikut:

Tabel 1 Nilai Interpretasi Pakar

\begin{tabular}{|l|c|}
\hline \multicolumn{1}{|c|}{ Uncertain term } & CF \\
\hline Definitely not (pasti tidak) & -1.0 \\
\hline $\begin{array}{l}\text { Almost certainty not (hampir tidak } \\
\text { pasti) }\end{array}$ & -0.8 \\
\hline $\begin{array}{l}\text { Probably not (kemungkinan besar } \\
\text { tidak) }\end{array}$ & -0.6 \\
\hline Maybe not (mungkin tidak) & -0.4 \\
\hline Unknown (tidak tahu) & -0.2 to 0.2 \\
\hline Maybe (mungkin) & 0.4 \\
\hline Probably (kemungkinan besar) & 0.6 \\
\hline Almost certainty (hampir pasti) & 0.8 \\
\hline Definitely & 1.0 \\
\hline
\end{tabular}

Sumber: Sutojo dkk (2011)

Nilai $\mathrm{CF}$ ada 2, yaitu nilai $\mathrm{CF}_{\text {rule }}$ (nilai melekat pada suatu kaidah/rule tertentu dan besarnya nilai diberikan oleh pakar) dan nilai $\mathrm{CF}_{\text {user }}$ (nilai yang diberikan oleh pengguna mewakili derajat kepastian/keyakinan atas gejala yang dialami kelinci). Pada proses pencarian kesimpulan menggunakan rumus certainty factor untuk menentukan status hasil diagnosis. Rumus certainty factor pada sistem pakar untuk mendiagnosis penyakit pada kelinci ini adalah:

$$
C F(H, E)=C F(E) * C F(\text { rule })
$$

Nilai CF(rule) ditentukan oleh pakar, sedangkan nilai $\mathrm{CF}(\mathrm{E})$ ditentukan oleh pengguna saat memilih gejala pada aplikasi sistem pakar.

Suatu sistem pakar seringkali memiliki kaidah lebih dari satu dan terdiri dari beberapa premis yang dihubungkan dengan AND atau OR. Formula CF untuk beberapa kaidah yang mengarah pada hipotesa yang sama menurut Kusrini (Latumakulita, 2012), dapat dituliskan sebagai berikut:

$$
C F(H)=\begin{aligned}
& C F(R 1)+C F(R 2)-[C F(R 1) * C F(R 2)] \\
& ; \text { Nilai } \mathrm{CF}(\mathrm{R} 1) \text { dan } \mathrm{CF}(\mathrm{R} 2)>0 \\
& \\
& C F(R 1)+C F(R 2)+[C F(R 1) * C F(R 2)] \\
& ; \text { Nilai } C F(\mathrm{R} 1) \text { dan } \mathrm{CF}(\mathrm{R} 2)<0 \\
& \frac{C F(R 1)+C F(R 2)}{1-\min [|C F(R 1)|,|C F(R 2)|]} \\
& ; \text { Nilai } \mathrm{CF}(\mathrm{R} 1) \text { dan } \mathrm{CF}(\mathrm{R} 2) \text { berlawanan tanda }
\end{aligned}
$$

Rumus 1 untuk menghitung nilai CF pada setiap rule dengan gejala tunggal. Pada implementasi sistem pakar diagnosis penyakit pada kelinci menggunakan rumus:

$C F(R 1, R 2)=C F(R 1)+C F(R 2)-[(C F(R 1) * C F(R 2)]$ karena nilai $C F$ yang diberikan bernilai positif. Rumus 2 digunakan untuk menghitung rule gejala tunggal yang memiliki kesimpulan yang sama.

\section{Hasil}

Menurut Duval et al (Rohajawati, 2010), Sistem pakar memiliki 3 bagian utama, yaitu knowledge base (tempat penyimpanan informasi yang aktual), inference engine (proses penalaran untuk pencarian solusi dan kesimpulan yang datanya dikirim oleh user dan fakta- faktanya tersimpan pada knowledge base,) dan user interface (layar sajian menu untuk sistem pakar berkomunikasi dengan user).

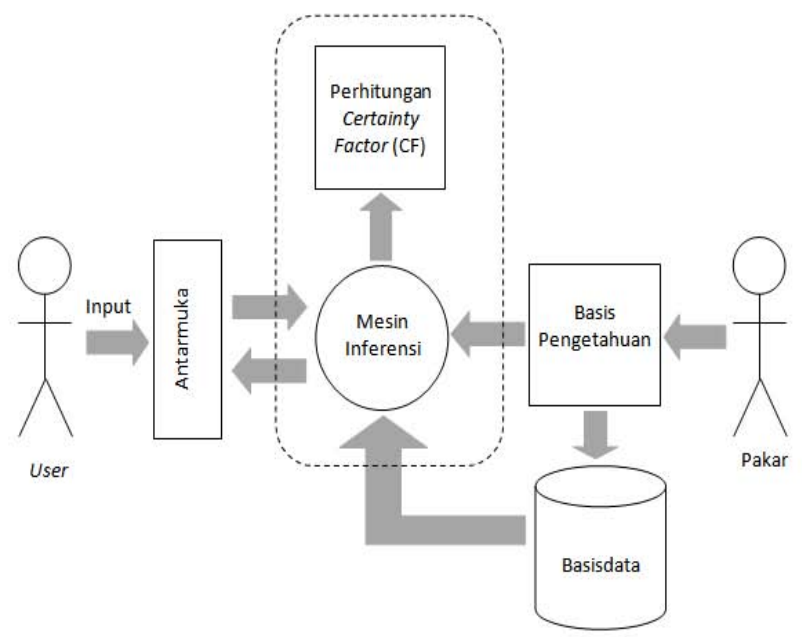

Gambar 1 Diagram Blok Sistem 
Knowledge base dapat berupa susunan tabel yang saling berelasi antar satu dengan yang lainnya. Data yang terkait dengan gejala dan penyebab penyakit pada kelinci disimpan di sini. Konsep user interface dikembangkan dengan pembuatan antar muka yang user friendly sehingga memudahkan dalam pengisian data dan fakta. Keluaran yang disajikan berupa informasi nilai kepercayaan jenis penyakit yang didiagnosis menyerang. Selain itu, pengembangan dan pembangunan aplikasi digunakan PHP dan MySQL sebagai tools language dalam konstruksinya.

\section{a. Representasi Pengetahuan}

Pengetahuan yang diperoleh dari pakar direpresentasikan ke dalam format yang dipahami manusia dan dapat dieksekusi oleh komputer dengan menggunakan teknik kaidah produksi. Kaidah produksi berupa aturan (rule) yang berupa IF (kondisi) THEN (aksi) dimana kondisi merupakan bagian dari awal yang mengekspresikan situasi (pernyataan bearawal IF) dan aksi merupakan bagian yang menyatakan suatu tindakan tertentu yang diharapkan jika suatu situasi bernilai benar (pernyataan berawal THEN). Pengetahuan diperoleh dari hasil studi pustaka, literatur-literatur tentang penyakit kelinci dan wawancara secara langsung dengan pakar (dokter hewan). Berikut penyakit beserta kode penyakitnya:

Tabel 2 Tabel Penyakit

\begin{tabular}{|c|l|}
\hline KODEP & \multicolumn{1}{|c|}{ PENYAKIT } \\
\hline P00001 & $\begin{array}{l}\text { Kembung } \\
\text { (Enterititis Kompleks) }\end{array}$ \\
\hline P00002 & Diare (Mencret) \\
\hline P00003 & Pilek Dan Gangguan Pernapasan \\
\hline P00004 & Demodexcosis \\
\hline P00005 & Scabies \\
\hline P00006 & Radang / Iritasi Mata \\
\hline P00007 & Coccidiosis \\
\hline P00008 & Cacingan \\
\hline P00009 & Myxomatosis \\
\hline P00010 & Sembelit (Konstipasi) \\
\hline P00011 & $\begin{array}{l}\text { Radang Susu / Young Do Syndrome / } \\
\text { Mastitis }\end{array}$ \\
\hline P00012 & Radang Paru-Paru / Pneumonia \\
\hline P00013 & Favus / Infeksi Kulit Kepala \\
\hline
\end{tabular}

Sedangkan gejala penyakit dan kode gejalanya sebagai berikut:

Tabel 3 Tabel Gejala

\begin{tabular}{|c|l|}
\hline KODEG & \multicolumn{1}{|c|}{ GEJALA } \\
\hline G00001 & Air kencing berkurang banyak \\
\hline G00002 & Air mata berlebihan \\
\hline G00003 & Batuk \\
\hline G00004 & Bau badan tidak enak \\
\hline G00005 & Bengkak pada daerah kepala \\
\hline G00006 & Berat badan menurun \\
\hline G00007 & Bersin-bersin \\
\hline G00008 & Bulu kusam \\
\hline G00009 & Bulu langsung hilang sama sekali \\
\hline G00010 & Bulu rontok \\
\hline
\end{tabular}

\begin{tabular}{|c|c|}
\hline KODEG & GEJALA \\
\hline G00011 & Keluar cairan kuning dari mata \\
\hline G00012 & Daun telinga menurun \\
\hline G00013 & Dehidrasi \\
\hline G00014 & Demam tinggi \\
\hline G00015 & Depresi / stress \\
\hline G00016 & Gelisah \\
\hline G00017 & Kaki basah oleh cairan ingus \\
\hline G00018 & Kaki depan dimasukkan ke tempat minum \\
\hline G00019 & Menggaruk-garuk pada kulit yang terinfeksi \\
\hline G00020 & Kelopak mata membengkak \\
\hline G00021 & $\begin{array}{l}\text { Keluar cairan keruh kental dari hidung } \\
\text { (pilek) }\end{array}$ \\
\hline G00022 & Keluar cairan kuning dari hidung \\
\hline G00023 & Kepala sering diangkat tinggi-tinggi \\
\hline G00024 & Kornea mata berkabut \\
\hline G00025 & Kotoran encer \\
\hline G00026 & Kulit kemerahan dan gatal \\
\hline G00027 & Kulit tebal dan kemerah-merahan \\
\hline G00028 & Lesu \\
\hline G00029 & Malas \\
\hline G00030 & Mata bernanah \\
\hline G00031 & Mata dan telinga kebiru-biruan \\
\hline G00032 & Mata suram agak menutup \\
\hline G00033 & Badan membungkuk \\
\hline G00034 & Kotoran keras \\
\hline G00035 & Diare berdarah \\
\hline G00036 & $\begin{array}{l}\text { Mengangkat kaki dan meletakkannya agak } \\
\text { kedepan }\end{array}$ \\
\hline G00037 & $\begin{array}{l}\text { Menggosokkan puting susunya pada dinding } \\
\text { kandang }\end{array}$ \\
\hline G00038 & Mengkerot-kerotkan gigi \\
\hline G00039 & Nafas cepat \\
\hline G00040 & Nafsu makan menurun \\
\hline G00041 & Nafsu makan tidak menentu \\
\hline G00042 & Pantat / anus kotor \\
\hline G00043 & Penebalan kulit \\
\hline G00044 & Pertumbuhan terhambat \\
\hline G00045 & Perut membesar \\
\hline G00046 & Pucat \\
\hline G00047 & puting susu bengkak dan keras \\
\hline G00048 & puting susu berwarna merah atau kebiruan \\
\hline G00049 & Air susu terasa panas \\
\hline G00050 & Radang mata \\
\hline G00051 & Radang pada kulit \\
\hline G00052 & Radang selaput mata \\
\hline G00053 & Selalu dekat dengan tempat minum \\
\hline $\mathrm{G} 00054$ & Sering menggaruk-garuk badan \\
\hline G00055 & Sesak nafas \\
\hline G00056 & Suhu tubuh tidak menentu \\
\hline G00057 & Sulit buang kotoran \\
\hline G00058 & Sulit untuk makan dan minum \\
\hline G00059 & Terbentuk keropeng di telinga dan atau kaki \\
\hline G00060 & Tubuh kurus \\
\hline G00061 & Tidak mau menyusui anaknya \\
\hline G00062 & Wajah agak perot \\
\hline G00063 & Bengkak pada alat genital \\
\hline G00065 & Tidak mau makan \\
\hline G00066 & Suhu tubuh naik \\
\hline G00067 & Timbul sisik di kulit kepala \\
\hline G00068 & Kulit kepala tampak pecah-pecah \\
\hline
\end{tabular}


Setelah diketahui data penyakit serta gejalanya, dibuatlah basis pengetahuan berupa tabel keputusan sistem pakar. Lalu membuat kaidah produksi berupa aturan IF-THEN. Aturan ini dibuat untuk menterjemahkan tabel-tabel kaidah sebagai alat bantu untuk mengetahui jenis penyakit pada kelinci. Aturan seperti pada tabel dibawah ini:

Tabel 4 Tabel kaidah produksi (if...then)

\begin{tabular}{|c|c|}
\hline IF & THEN \\
\hline $\begin{array}{l}\text { G00012 AND G00018 AND G00032 } \\
\text { AND G00033 AND G00038 AND } \\
\text { G00039 AND G00053 }\end{array}$ & P00001 \\
\hline 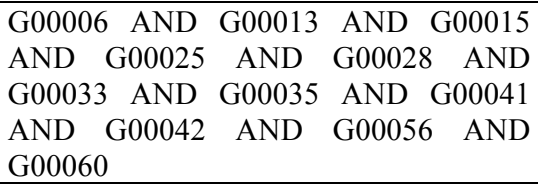 & P00002 \\
\hline $\begin{array}{l}\text { G00002 AND G00003 AND G00007 } \\
\text { AND G00017 AND G00021 AND } \\
\text { G00052 AND G00055 AND G00066 }\end{array}$ & P00003 \\
\hline $\begin{array}{l}\text { G00004 AND G00006 AND G00010 } \\
\text { AND G00014 AND G00015 AND } \\
\text { G00016 AND G00026 AND G00028 } \\
\text { AND G00040 AND G00043 AND } \\
\text { G00044 AND G00054 AND G00060 }\end{array}$ & P00004 \\
\hline 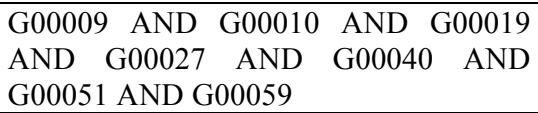 & P00005 \\
\hline $\begin{array}{l}\text { G00002 AND G00020 AND } \text { G00024 } \\
\text { AND G00030 AND G00050 }\end{array}$ & P00006 \\
\hline $\begin{array}{l}\text { G00006 AND G00008 AND G00013 } \\
\text { AND G00015 AND } \text { G00028 } \\
\text { G00035 AND G00038 AND G00040 } \\
\text { AND G00044 AND G00045 AND } \\
\text { G00046 AND G00055 }\end{array}$ & P00007 \\
\hline $\begin{array}{l}\text { G00002 AND G00008 AND G00028 } \\
\text { AND G00040 AND G00041 AND } \\
\text { G00046 AND G00060 AND G00065 }\end{array}$ & P00008 \\
\hline $\begin{array}{l}\text { G00005 AND G00008 AND G00011 } \\
\text { AND G00012 AND G00022 AND } \\
\text { G00040 AND G00050 AND G00058 } \\
\text { AND G00062 AND G00063 }\end{array}$ & P00009 \\
\hline $\begin{array}{llll}\text { G00001 } & \text { AND } & \text { G00016 } & \text { AND } \\
\text { AND G00029 } \\
\text { G00057 } & & & \\
\end{array}$ & P00010 \\
\hline $\begin{array}{l}\text { G00013 AND G00014 AND G00037 } \\
\text { AND G00040 AND G00047 AND } \\
\text { G00048 AND G00049 AND G00061 }\end{array}$ & P00011 \\
\hline $\begin{array}{l}\text { G00023 AND G00025 AND G00031 } \\
\text { AND G00055 }\end{array}$ & P00012 \\
\hline G00010 AND G00067 AND G00068 & $\mathrm{P} 00013$ \\
\hline
\end{tabular}

Dari penyakit-penyakit yang telah disebutkan pada tabel 2 serta gejala-gejala yang ditampilkan pada tabel 3, pakar memberikan nilai CF. Nilai CF didapat dari interpretasi "term" dari pakar seperti pada tabel 1 . Rentang nilai yang dipakai oleh pakar adalah dari 0,2 - 1. Pada sesi konsultasi sistem, user diberi lima pilihan jawaban yang masing-masing memiliki bobot sebagai berikut:

$\begin{array}{ll}\text { - } \quad \text { Tidak tahu } & =0,2 \\ \text { - } \quad \text { Mungkin } & =0,4 \\ \text { - } \quad \text { Kemungkinan besar } & =0,6\end{array}$

$$
\begin{array}{ll}
\text { - Hampir pasti } & =0,8 \\
\text { - } \quad \text { Pasti } & =1
\end{array}
$$

b. Perancangan Basisdata

Basis data dibuat menggunakan MySQL. Dalam perancangan sistem pakar ini dibuat 4 tabel untuk menyimpan data yang sudah diproses. Susunan ERD yang dirancang dapat dilihat pada gambar 2 dan relasi antar tabel digambarkan pada gambar 3 .

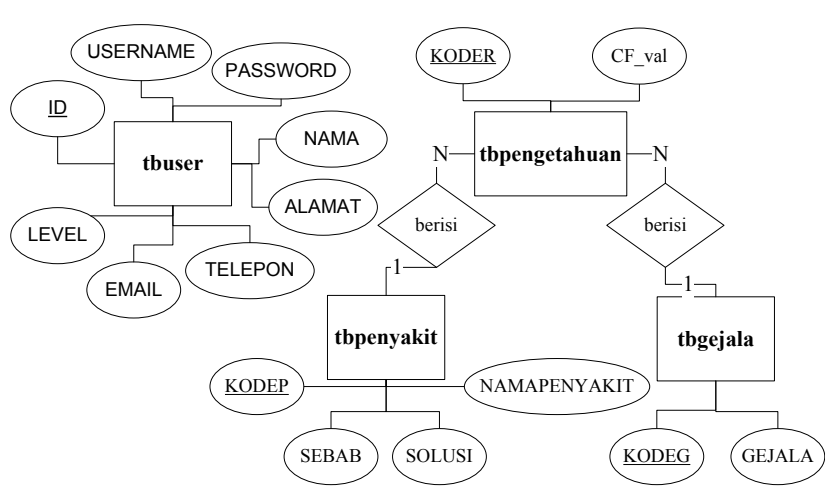

Gambar 2 Entity Relationship Diagram

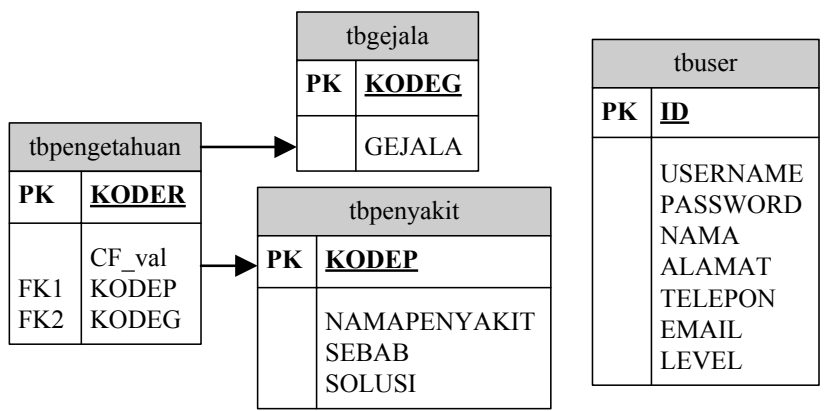

Gambar 3 Diagram Relasi Basis Data

c. Perancangan Sistem

Dalam merancang sistem, dilakukan dengan membuat flowchart sistem dan diagram konteks. Flowchart sistem seperti pada gambar 4. Selain flowchart sistem, terdapat pula flowchart proses diagnosis penyakit yaitu pada gambar 5 .

Diagram konteks mempunyai tiga terminator dan satu proses, dimana proses ini mencakup proses secara keseluruhan dari aplikasi. Aliran data bersumber pada pakar yang memberikan input berupa data-data gejala, penyakit, serta pengetahuan dan data pendukung lainnya. Outputnya adalah end user dapat melihat hasil diagnosis penyakit yang diderita oleh kelinci tersebut yang kemudian dapat dilihat penjelasan dan cara pengobatan dari penyakit yang diderita.

Dari penjelasan tersebut maka dapat digambarkan diagram konteks untuk sistem pakar untuk melakukan diagnosis penyakit pada kelinci pada gambar 6 . 


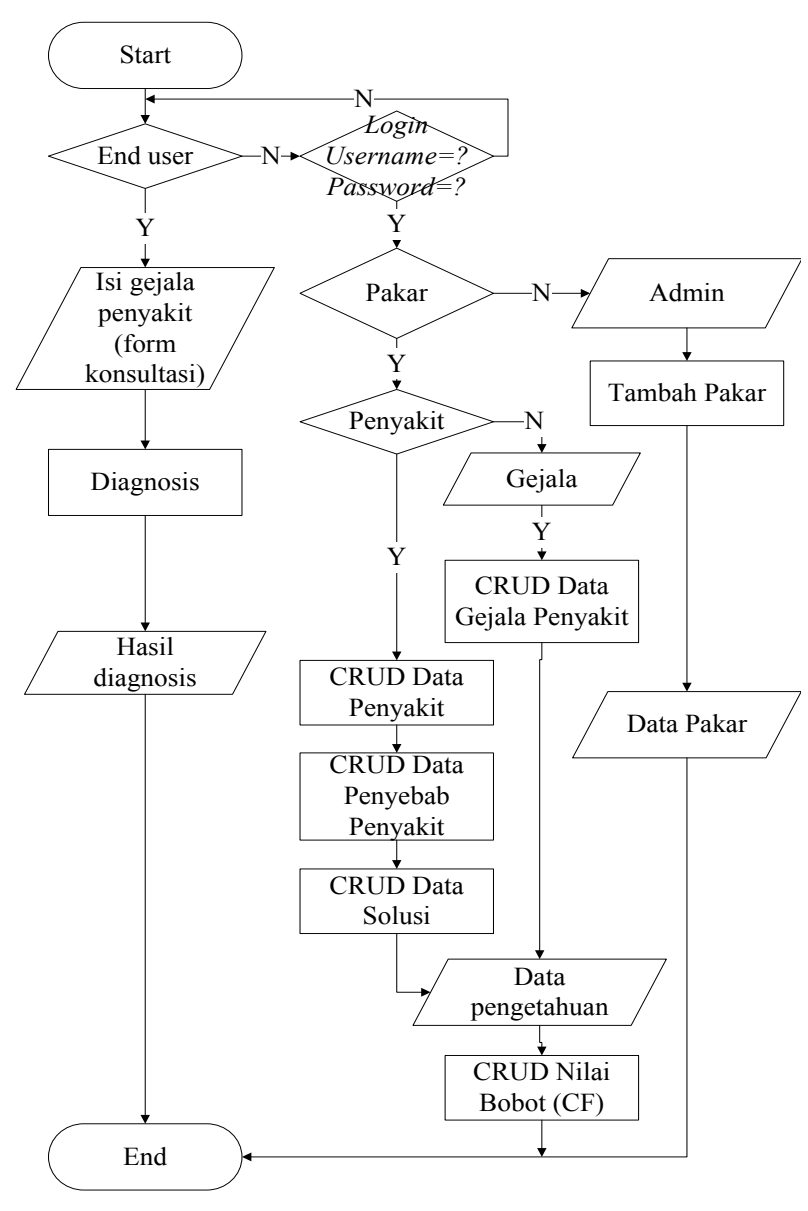

Gambar 4 Flowchart Sistem
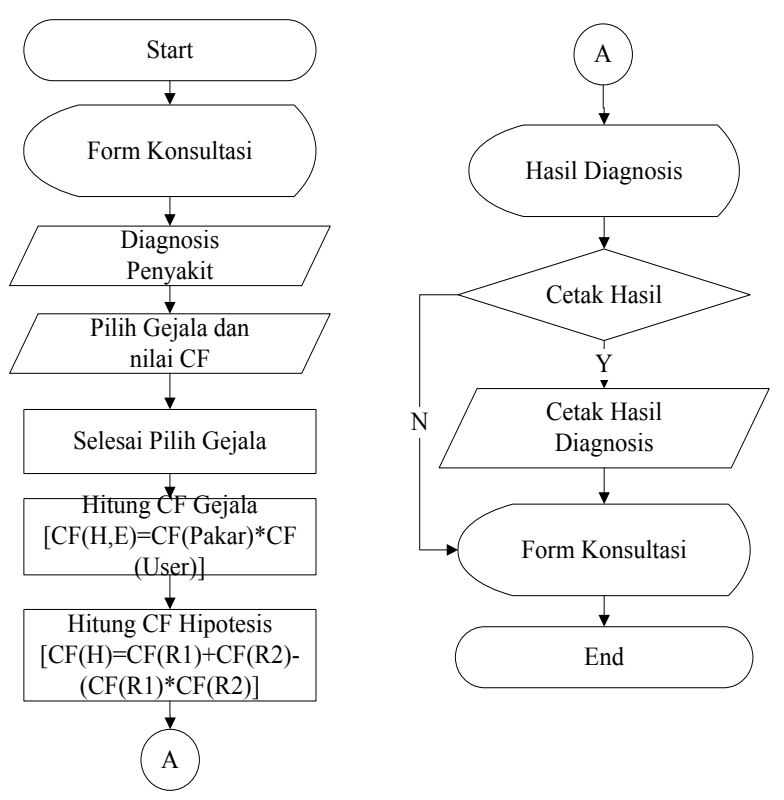

Gambar 5 Flowchart Proses Diagnosis Penyakit

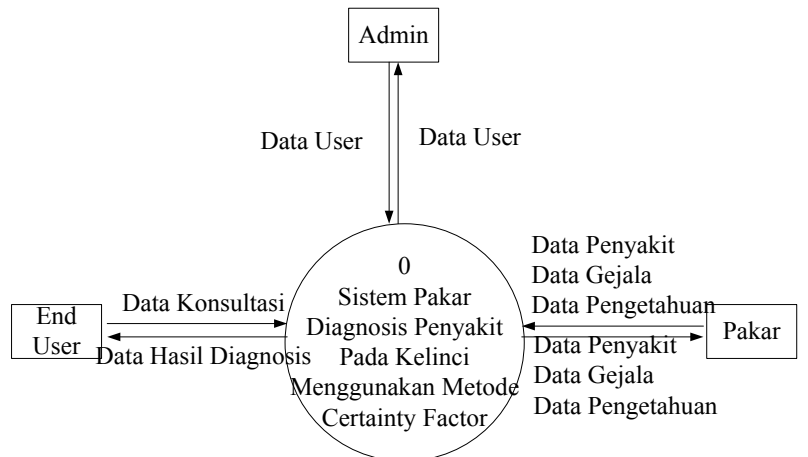

Gambar 6 Diagram Konteks Sistem

\section{Pembahasan}

a. Pengujian Fungsional dan Sistem

Untuk mengetahui hasil diagnosis penyakit, maka dilakukan pengujian proses diagnosis. Proses pengujian berupa memasukkan data gejala beserta nilai kepercayaan/kemungkinannya. Setelah proses diagnosis berhasil dilakukan, maka sistem akan menampilkan hasil diagnosis berupa kemungkinan penyakit yang diderita disertai dengan prosentase besarnya kepercayaan terhadap kemungkinan penyakit tersebut. Data gejala yang dimasukkan yaitu:

- Air susu terasa panas

- Gelisah

- Kulit kemerahan dan gatal

- Mengkerot-kerotkan gigi

- Menggosokkan puting susunya pada dinding kandang

- Puting susu bengkak dan keras

Setelah memasukkan data ke sistem, hasil diagnosis pada pengujian sistem adalah penyakit Radang Susu / Young Do Syndrome / Mastitis dengan nilai kepastian $98.4 \%$ yang ditampilkan oleh output seperti gambar 7 berikut:

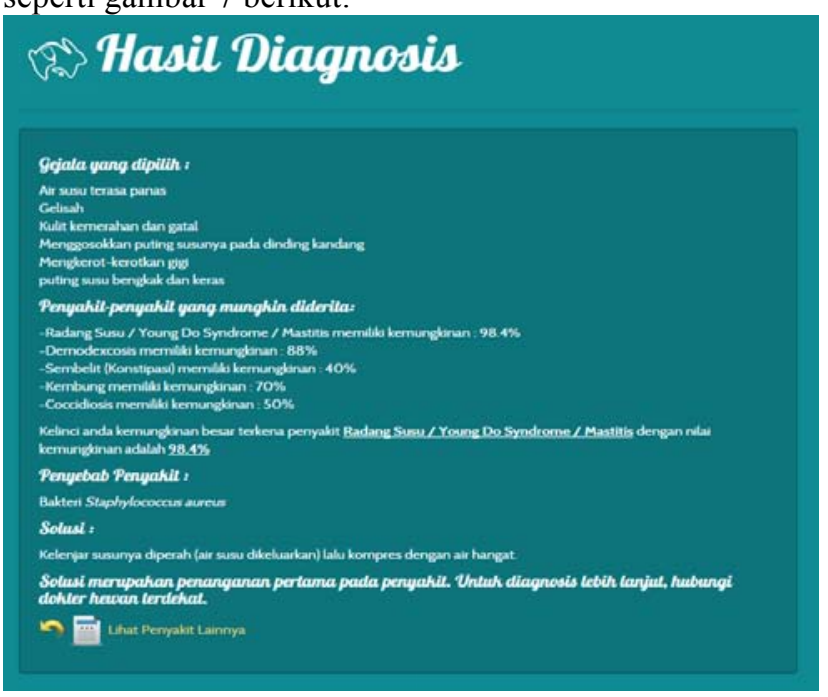

Gambar 7 Hasil Diagnosis

b. Analisa Perhitungan Certainty Factor (CF)

Pertama memilih gejala beserta nilai kepercayaannya. Adapun gejala yang dipilih beserta nilai $\mathrm{CF}$ yang dimasukkan sebagai berikut: 
- $\quad$ Air kencing berkurang banyak (A), $\mathrm{CF}_{\text {user }}(\mathrm{A})=1$

- $\quad$ Badan membungkuk (B), $\mathrm{CF}_{\text {user }}(\mathrm{B})=0,4$

- $\quad$ Dehidrasi $(\mathrm{C}), \mathrm{CF}_{\text {user }}(\mathrm{C})=0,4$

- Depresi / stress (D), $\mathrm{CF}_{\text {user }}(\mathrm{D})=0,4$

- $\quad$ Gelisah (E), $\mathrm{CF}_{\text {user }}(\mathrm{E})=0,8$

- $\quad$ Kotoran keras $(\mathrm{F}), \mathrm{CF}_{\text {user }}(\mathrm{F})=1$

- $\operatorname{Malas}(\mathrm{G}), \mathrm{CF}_{\text {user }}(\mathrm{G})=0,8$

- $\quad$ Nafsu makan menurun $(\mathrm{H}), \mathrm{CF}_{\text {user }}(\mathrm{H})=0,8$

Dari gejala yang telah dipilih muncul rules dari gejala-gejala tersebut, yaitu:

Rule 1 = IF B THEN Kembung

Rule 2 = IF B AND C AND D THEN Berak Darah / Mencret

Rule 3 = IF D AND E AND H THEN Demodexcosis

Rule $4=$ IF H THEN Scabies

Rule $5=$ IF C AND D AND H THEN Coccidiosis

Rule $6=$ IF H THEN Cacingan

Rule 7 = IF H THEN Myxomatosis

Rule $8=$ IF A AND E AND F AND G AND H THEN Sembelit

Rule $9=$ IF C AND H THEN Radang Susu/Youngdoe syndrome/Mastitis

Setelah diketahui rules yang muncul, menentukan nilai $\mathrm{CF}$ pakar dari masing-masing gejala sebagai berikut:

Tabel $5 \mathrm{CF}_{\text {pakar }}$

\begin{tabular}{|c|c|c|c|c|c|c|c|c|c|}
\hline & $\begin{array}{c}\text { Rule } \\
\mathbf{1}\end{array}$ & $\begin{array}{c}\text { Rule } \\
\mathbf{2}\end{array}$ & $\begin{array}{c}\text { Rule } \\
\mathbf{3}\end{array}$ & $\begin{array}{c}\text { Rule } \\
\mathbf{4}\end{array}$ & $\begin{array}{c}\text { Rule } \\
\mathbf{5}\end{array}$ & $\begin{array}{c}\text { Rule } \\
\mathbf{6}\end{array}$ & $\begin{array}{c}\text { Rule } \\
\mathbf{7}\end{array}$ & $\begin{array}{c}\text { Rule } \\
\mathbf{8}\end{array}$ & $\begin{array}{c}\text { Rule } \\
\mathbf{9}\end{array}$ \\
\hline A & & & & & & & & 0,6 & \\
\hline B & 0,4 & 0,7 & & & & & & & \\
\hline C & & 0,4 & & & 0,4 & & & & 0,4 \\
\hline D & & 0,4 & 0,4 & & 0,4 & & & & \\
\hline E & & & 0,6 & & & & & 0,4 & \\
\hline F & & & & & & & & 0,7 & \\
\hline G & & & & & & & & 0,4 & \\
\hline H & & & 0,4 & 0,4 & 0,4 & 0,5 & 0,4 & 0,8 & 0,4 \\
\hline
\end{tabular}

Dari rules diatas, rule yang memiliki gejala majemuk, dipecah sehingga rule memiliki gejala tunggal. Setelah rule tunggal terbentuk lalu menghitung nilai kepercayaannya. Perhitungan dimulai dengan menghitung $\mathrm{CF}_{\text {pakar }}$ dengan $\mathrm{CF}_{\text {user }}$ dengan menggunakan persamaan 1. Setelah itu mengkombinasikan $\mathrm{CF}$ tersebut ke dalam $\mathrm{CF}$ kombinasi dengan persamaan 2.

Berikut perhitungan pada rule 8:

- Perhitungan persamaan 1

$$
\begin{aligned}
& \mathrm{CF} 8.1=(\mathrm{A}) *(\mathrm{~A})(\mathrm{R} 8)=1 * 0,6=0,6 \\
& \mathrm{CF} 8.2=(\mathrm{E}) *(\mathrm{E})(\mathrm{R} 8)=0,8 * 0,4=0,32 \\
& \mathrm{CF} 8.3=(\mathrm{F}) *(\mathrm{~F})(\mathrm{R} 8)=1 * 0,7=0,7 \\
& \mathrm{CF} 8.4=(\mathrm{G}) *(\mathrm{G})(\mathrm{R} 8)=0,8 * 0,4=0,32 \\
& \mathrm{CF} 8.5=(\mathrm{H}) *(\mathrm{H})(\mathrm{R} 8)=0,8 * 0,8=0,64 \\
& \text { - Perhitungan persamaan } 2 \\
& \mathrm{CF}_{\text {kombinasi }}(\mathrm{CF} \text { 8.1, } \mathrm{CF} 8.2)=0,6+0,32- \\
& (0,6 * 0,32)=0,728 \\
& \mathrm{CF}_{\text {kombinasi }}\left(\mathrm{CF} 8.3, \mathrm{CF} 8_{\text {old } 1}\right)=0,7+0,728- \\
& (0,7 * 0,728)=0,9184 \\
& \mathrm{CF}_{\text {kombinasi }}\left(\mathrm{CF} 8.4, \mathrm{CF} 8_{\text {old } 2}\right)=0,32+0,9184- \\
& (0,32 * 0,9184)=0,944512
\end{aligned}
$$

$\mathrm{CF}_{\text {kombinasi }}\left(\mathrm{CF} 8.5, \mathrm{CF} 8_{\text {old3 }}\right)=0,64+0,944512-$ $(0,64 * 0,944512)=0,98002432$

Pada rule 8, menghasilkan nilai kemungkinan 0,9800243332 yang bila di prosentasekan 98\%. Sedangkan perhitungan pada rule 9 adalah sebagai berikut:

- Perhitungan persamaan 1

$$
\begin{aligned}
& \text { CF } 9.1=(\mathrm{C}) *(\mathrm{C})(\mathrm{R} 9)=0,4 * 0,4=0,16 \\
& \text { CF } 9.2=(\mathrm{H}) *(\mathrm{H})(\mathrm{R} 9)=0,8 * 0,4=0,32
\end{aligned}
$$

- Perhitungan persamaan 2

$$
\begin{gathered}
\mathrm{CF}_{\text {kombinasi }}(\mathrm{CF} 9.1, \mathrm{CF} 9.2)=0,16+0,32- \\
\left(0,16^{*} 0,32\right)=0,4288
\end{gathered}
$$

Pada rule 9, menghasilkan nilai kemungkinan 0,4288 yang bila di prosentasekan $42,88 \%$. Dari perhitungan diatas, penyakit yang memiliki nilai kepercayaan tertinggi adalah pada rule 8 yaitu penyakit Sembelit.

\section{Simpulan dan Saran}

Penerapan metode Certainty Factor (CF) menggunakan basis pengetahuan (knowledgde base) dan mesin inferensi dapat digunakan untuk membangun suatu sistem pakar berbasis web untuk diagnosa penyakit pada kelinci berdasarkan pada beberapa fakta dan gejala. Sistem pakar yang dibangun dapat mengenali dan mengetahui penyakit pada kelinci menggunakan metode certainty factor (CF) dan menghasilkan solusi untuk membantu penanganan pada penyakit. Sistem pakar ini bukan untuk menggantikan kedudukan seorang ahli maupun pakar, tetapi untuk memasyarakatkan pengetahuan dan pengalaman pakar-pakar yang ahli di bidangnya.

\section{Daftar Rujukan}

Alatas, Sofia., Maulidia G., Keegan (2009): Sistem Pakar Berbasis Web Untuk Diagnosa Penyakit Melalui Pemeriksaan Mulut, thesis.binus.ac.id/Asli/Cover/2009-2-00175IF\%20Cover.pdf [Februari 2014]

Ermawati, Dwi dan Tim Redaksi Cemerlang (2011): Untung Menggiurkan Dari Budidaya Kelinci, Penerbit Andi, Yogyakarta.

Milwati, Fitri Indah (2010): Sistem Pakar Untuk Memprediksi Jenis Penyakit Pada Kelinci Dengan Metode Forward Chaining, http://eprints.upnjatim.ac.id/1984/,

Undergraduate thesis, Faculty of Industrial Technology. [Januari 2014]

Latumakulita, Luther A. (2012) : Sistem Pakar Pendiagnosa Penyakit Anak Menggunakan Certainty Factor (Cf), Jurnal Ilmiah Sains Vol. 12 No. 2, Oktober 2012.

Rohajawati, Siti. Supriyati, Rina (2010): Sistem Pakar: Diagnosis Penyakit Unggas Dengan Metode Certainty Factor, CommIT, Vol. 4 No. 1 Mei 2010, hlm. 41 - 46.

Sutojo, T., Mulyanto, Edy, dan Suhartono, Vincent (2011) : Kecerdasan Buatan, Penerbit Andi, Yogyakarta, UDINUS, Semarang 